\title{
A New Expanded Host Range of Cucurbit yellow stunting disorder virus Includes Three Agricultural Crops
}

\author{
William M. Wintermantel, Laura L. Hladky, and Arturo A. Cortez, USDA-ARS, 1636 East Alisal Street, Salinas, \\ CA 93905; and Eric T. Natwick, University of California Desert Research and Extension Center, 1050 East Holton \\ Road, Holtville, CA 92250
}

\begin{abstract}
Wintermantel, W. M., Hladky, L. L., Cortez, A. A., and Natwick, E. T. 2009. A new expanded host range of Cucurbit yellow stunting disorder virus includes three agricultural crops. Plant Dis. 93:685-690.

Cucurbit yellow stunting disorder virus (CYSDV) was identified in the fall of 2006 affecting cucurbit production in the southwestern United States (California, Arizona), as well as in nearby Sonora, Mexico, resulting in nearly universal infection of fall melon crops in 2006 and 2007, and late infection of 2007 spring melons. Survival of CYSDV through the largely cucurbit-free winter months suggested the presence of weed or alternate crop hosts, although previous studies indicated a limited host range restricted to members of the Cucurbitaceae. To determine potential reservoir hosts for CYSDV in desert production, weed and crop hosts were collected from throughout the region over a period of 26 months, and were tested for the presence of CYSDV by reverse transcription-polymerase chain reaction (RT-PCR) using CYSDV HSP70h- and coat protein gene-specific primers. Many noncucurbits collected from infected melon fields and nearby areas were symptomless and virus free; however, CYSDV was detected in alfalfa (Medicago sativa), lettuce (Lactuca sativa), and snap bean (Phaseolus vulgaris), as well as in several weed species widely prevalent in the region. Typical crinivirus symptoms of interveinal yellowing and leaf brittleness were observed on CYSDV-infected snap bean, alkali mallow (Sida hederacea) and Wright's groundcherry (Physalis wrightii), while other infected crop and weed hosts were symptomless. Transmission tests demonstrated that lettuce, snap bean, alkali mallow, Wright's groundcherry, and buffalo gourd (Cucurbita foetidissima) could serve as virus reservoir hosts for transmission of CYSDV to melon and other cucurbits. These results expand the previously known host range of CYSDV, demonstrating that the virus is capable of infecting not only members of the Cucurbitaceae, but also plants in seven additional taxonomic families.
\end{abstract}

The identification of Cucurbit yellow stunting disorder virus (CYSDV) in the fall of 2006 affecting cucurbit production in the Sonoran Desert region $(3,12)$ was of great concern to the American melon industry. California and Arizona produce the majority of American cantaloupe and honeydew melon and a large portion of U.S. watermelon (4). The areas in these states affected by CYSDV to date include the Imperial Valley of California, the adjacent Yuma, AZ region, and south-central Arizona. Additional production is found in the state of Sonora, Mexico, immediately south of Arizona and California. In 2006 when CYSDV first emerged in the region, Imperial Co., CA produced 114,305 metric

Corresponding author: William M. Wintermantel E-mail: bill.wintermantel@ars.usda.gov

* The $\boldsymbol{e}$-Xtra logo stands for "electronic extra" and indicates that two additional figures are available online.

Accepted for publication 29 March 2009.

doi:10.1094/PDIS-93-7-0685

This article is in the public domain and not copyrightable. It may be freely reprinted with customary crediting of the source. The American Phytopathological Society, 2009. tons of melons and 31,761 metric tons of watermelon, with a total value of US\$53.1 million (2). Arizona produced melons (cantaloupe, watermelon, and mixed melon) on approximately 36,500 acres (K. Nolte, personal communication), nearly all in areas now affected by CYSDV.

Impact of the virus outbreak was immediate and widespread, with nearly $100 \%$ infection of fall melon crops in 2006 (12) and 2007, and more limited infection of 2007 and 2008 spring melon crops, with infection of the spring crops occurring shortly before harvest. The epidemics coincided with gradually increasing populations of Bemisia tabaci, biotype $\mathrm{B}$, the whitefly vector responsible for transmission of CYSDV. During the initial outbreak of CYSDV, infected melon fields throughout the Imperial Valley and Yuma production region ranged from close proximity to one another to distant. For example, one infected melon field was at least 50 miles from the next nearest melon field.

CYSDV was first discovered in 1982 in the United Arab Emirates (10), and has since spread throughout numerous Mediterranean countries and the Middle East $(1,5,7,16,21)$. The first identification of CYSDV in North America occurred in the Rio Grande Valley of Texas in 1999 (11).
The virus remained confined to the Rio Grande Valley until the fall of 2006, when it emerged in the Sonoran Desert melon production region $(3,12)$. In 2007, CYSDV was found in the southeastern United States (Florida) as well (17). Initial symptoms of CYSDV on cucurbits consist of leaf mottling that eventually coalesces, resulting in interveinal chlorosis or yellowing, with major veins remaining predominantly green $(5,21)$. CYSDV infection causes a 30 to $50 \%$ reduction in yield $(1,15)$ resulting from a dramatic decrease in fruit sugar (brix). The virus has a relatively long latent period in infected plants, often not inducing symptoms until 3 to 4 weeks after infection by viruliferous whiteflies (21).

Previous studies indicated a very narrow host range for CYSDV, restricted to members of the Cucurbitaceae (5). Subsequent research identified lettuce as an experimental host (21) for use in differential host range analyses, although the virus had not been detected in lettuce from the field. Criniviruses have widely diverse host ranges, from Beet pseudo yellows virus, which infects an exceptionally broad array of hosts including members of at least 12 taxonomic families $(8,18,19)$, to CYSDV, which with the exception of lettuce was believed to be restricted to members of the Cucurbitaceae.

Melon production ceases in the Sonoran Desert region during the late fall and winter months, with new planting beginning in March and April. Survival of CYSDV during this period and its rapid reemergence in melons as whitefly populations increase following the largely cucurbit-free winter months suggested the possibility of as-yet-unidentified weed or alternate crop hosts that could serve as virus reservoirs. This was particularly apparent following an extended freeze in January 2007 that likely would have killed most nonperennials, including most volunteer melons. Such alternate host reservoirs could provide a conduit from the fall to spring melon crops. Similarly, alternate hosts may provide a reservoir to facilitate early infection of fall melon crops by providing a steady source of virus for the rapidly increasing whitefly vector population.

In order to gain knowledge of potential reservoir hosts in the desert melon production regions of California, Arizona, and northern Mexico, samples of possible non- 
cucurbit host plants were collected from areas in and near melon fields in California's Imperial Valley. Reverse transcriptionpolymerase chain reaction (RT-PCR) amplification of two regions of the CYSDV genome followed by DNA sequencing were used to verify infection of new hosts, and transmissions were conducted from approximately one-third of the newly identified hosts to confirm that whiteflies can transmit from these hosts back to cucurbits. This study greatly expands the previously known host range of CYSDV, identifying several reservoir hosts that can allow whiteflies to transmit CYSDV to cucurbits, and demonstrating CYSDV infection in members of seven taxonomic families in addition to the Cucurbitaceae.

\section{MATERIALS AND METHODS}

Virus isolates. The primary CYSDV isolate used for host range and vector transmission analysis was obtained from a commercial melon field in Imperial County, CA during the fall of 2006. This isolate, known as the Imperial Isolate, has been maintained in melon (Cucumis melo L.) and zucchini squash (Cucurbita pepo) in growth chambers at the USDA-ARS in Salinas, CA, and transferred from plant to plant by its whitefly vector, $B$. tabaci biotype B. Additional source plants consisted of field plants collected in and around melon fields in Imperial County, CA and Yuma County, AZ, that were confirmed to be infected with CYSDV using primers to the HSP70h gene (12) or the coat protein (CP) gene (17). Some source plants for transmission were developed by inoculation with the Imperial Isolate of CYSDV using B. tabaci biotype B. In such cases, melon or zucchini squash plants inoculated approximately 30 days earlier, expressing typical CYSDV interveinal yellowing symptoms and confirmed by RT-PCR to be infected by CYSDV, were used for transmission to test plant species of interest.

Vector source. Colonies of $B$. tabaci biotype $B$ were maintained virus-free in insect-proof cages in isolated growth rooms at temperatures ranging from 26 to $32^{\circ} \mathrm{C}$. The whitefly source colony was originally collected in 1990 from melon (Cucumis melo L.) in the Imperial Valley of California, and has been reared on broccoli (Brassica oleracea L.). The colony has been tested every 6 months on average by isozyme analysis (13) or RT-PCR using mitochondrial DNA primers (9) to confirm purity and prevent accidental contamination by alternate biotypes.

Sampling of wild plants for CYSDV. To determine potential reservoir hosts for CYSDV transmission in the desert production region, 210 weed and crop plants were collected from areas within and bordering fields containing CYSDV-infected melons, from September 2006 through November 2008. Infected fields were found in all areas of California's Imperial Valley and throughout the melon production region surrounding Yuma, AZ. Plants sampled are

Table 1. Detection of Cucurbit yellow stunting disorder virus in noncucurbit plant species from the Sonoran Desert ${ }^{\mathrm{a}}$

\begin{tabular}{|c|c|}
\hline Plants collected from fields & No. positive/no. tested \\
\hline \multicolumn{2}{|l|}{ Amaranthaceae } \\
\hline Amaranthus retroflexus (redroot pigweed) & $3 / 16$ \\
\hline Bassia hyssopifolia (five hook bassia) & $1 / 4$ \\
\hline \multicolumn{2}{|l|}{ Brassicaceae } \\
\hline Sisymbrium irio (London rocket) & $5 / 6$ \\
\hline \multicolumn{2}{|l|}{ Chenopodiaceae } \\
\hline Chenopodium album (lambsquarters) & $4 / 15$ \\
\hline Chenopodium murale (nettle leaf goosefoot) & $0 / 8$ \\
\hline \multicolumn{2}{|l|}{ Compositae } \\
\hline Helianthus аппииs (sunflower) & $0 / 3$ \\
\hline Lactuca sativa (lettuce) & $2 / 13$ \\
\hline Sonchus sp. (sowthistle) & $3 / 10$ \\
\hline \multicolumn{2}{|l|}{ Euphorbiaceae } \\
\hline Chamaesyce maculata (prostrate spurge) & $0 / 12$ \\
\hline Jatropha curcas (jatropha) & $0 / 5$ \\
\hline \multicolumn{2}{|l|}{ Fabaceae } \\
\hline Medicago sativa (alfalfa) & $18 / 20$ \\
\hline Melilotus indicus (sour clover) & $0 / 2$ \\
\hline Phaseolus vulgaris (snap bean) & $14 / 17$ \\
\hline \multicolumn{2}{|l|}{ Malvaceae } \\
\hline Abelmoschus esculentus (okra) & $0 / 7$ \\
\hline Abutilon theophrasti (velvet leaf) & $0 / 3$ \\
\hline Malva neglecta (common mallow) & $4 / 15$ \\
\hline Sida hederacea (alkali mallow) & $2 / 24$ \\
\hline \multicolumn{2}{|l|}{ Portulacaceae } \\
\hline Portulaca oleracea (purslane) & $0 / 2$ \\
\hline \multicolumn{2}{|l|}{ Solanaceae } \\
\hline Datura stramonium (jimsonweed) & $0 / 1$ \\
\hline Physalis wrightii (Wright's groundcherry) & $3 / 15$ \\
\hline Solanum elaeagnifolium (silverleaf nightshade) & $9 / 12$ \\
\hline Total collected & $68 / 210$ \\
\hline
\end{tabular}

a Samples collected from fall 2006 through fall 2008. listed in Table 1. The plant samples were examined for possible symptoms, total nucleic acids were extracted as described below, and extracts were tested for the presence of CYSDV by RT-PCR using CYSDV HSP70h- and/or CP gene-specific primers $(12,17)$. Positive controls consisted of total nucleic acid extract from CYSDV-infected melon or zucchini. Healthy control plants of each species, raised in a nursery greenhouse at the USDA-ARS in Salinas, CA, were used as negative controls for RT-PCR when possible. When known healthy sources were not available for field plants, healthy controls consisted of healthy melon, zucchini squash, or the closest known relative available. Healthy controls for all field infections were negative for CYSDV using both HSP70h and CP primer sets.

Vector transmission, experimental host range, and reservoir hosts. In order to determine the infectivity of CYSDV on noncucurbit plants, large numbers of $B$. tabaci biotype $\mathrm{B}$ were allowed acquisition access periods (AAP) of $48 \mathrm{~h}$ on CYSDVinfected cucumber, melon, or zucchini source plants, with source plant infections approximately 4 to 5 weeks old exhibiting strong symptoms. Following virus acquisition, whiteflies were transferred to leaf cages by briefly chilling them at $4{ }^{\circ} \mathrm{C}$ to immobilize them. Cages containing 40 to 100 whiteflies each were clipped to the underside of a leaf of each test plant for 48-h transmission periods. Following inoculation of plants with CYSDV via whiteflies, the plants were sprayed with Resmethrin (Whitmire Inc., St. Louis, MO) to kill adult and immature whiteflies, and placed in net cages (54 mesh) within growth chambers for 4 weeks. Growth chambers were maintained at $27^{\circ} \mathrm{C}$ with 14 -h days for the duration of experiments. One week postinoculation, inoculated leaves were removed from plants to prevent any remaining whitefly nymphs from maturing to adults.

In order to determine if newly identified noncucurbit and wild cucurbit hosts could serve as reservoirs of CYSDV for transmission back to cucurbits, transmissions were conducted from infected host plants to melon. CYSDV-infected leaves of newly identified hosts collected from field isolations as well as leaves from experimental host range tests were used as CYSDV sources. Adult B. tabaci biotype B were allowed 48-h AAP on infected source plant leaves of each test host, as well as melon (Cucumis melo 'Top Mark') and/or zucchini (Cucurbita pepo 'Black Beauty'). Following acquisition, whiteflies were placed in leaf cages that were subsequently clipped to melon or zucchini leaves ( 75 whiteflies per cage, one cage per plant), and transmissions were performed as described above for experimental host range tests.

Molecular analyses. Total nucleic acids were extracted from leaf tissue according 
to the method of Dellaporta et al. (6) or using Qiagen RNeasy Plant Mini Kits (Qiagen, Valencia, CA), and extracts were stored at -20 or $-80^{\circ} \mathrm{C}$. Positive controls for CYSDV consisted of total nucleic acid extracts from CYSDV-infected melon or zucchini. Negative controls were virus-free plants of test plant species as well as melon and zucchini. RT-PCR was used to amplify a 394-nt segment of the CYSDV CP gene corresponding to nts 5206 to 5600 of RNA2 (14; GenBank accession no. NC004810) (CysCP5206F 5' TTTGGA AAAGAACCTGACGAG 3'; CysCP5600R 5' TTCATCAACAGATTGGCTGC $3^{\prime}$ ) (17) and/or a 175-nt segment of the HSP70h gene corresponding to nts 1808 to 1982 of RNA2 (CYShspF 5' TGATGTATGACTTCGGAGGAGGAAC 3'; CYShspR 5' TCAGCGGACAAACCACCTTTC 3') (12). Total nucleic acid extracts (as well as positive and negative controls and reagent blanks) were reverse-transcribed using MMLV reverse transcriptase (Promega, Inc., Madison, WI) with reaction conditions of $42^{\circ} \mathrm{C}$ for $90 \mathrm{~min}$, and cDNA was amplified with Taq DNA polymerase (Promega). Amplification conditions consisted of 5 min denaturation at $95^{\circ} \mathrm{C}$, followed by 35 cycles of $95^{\circ} \mathrm{C}$ for $1 \mathrm{~min}$, $55^{\circ} \mathrm{C}$ for $1 \mathrm{~min}$, and $72^{\circ} \mathrm{C}$ for $1 \mathrm{~min}$., with a final extension at $72^{\circ} \mathrm{C}$ for $10 \mathrm{~min}$. RTPCR reaction products were separated by electrophoresis in $1 \%$ agarose gels and stained with ethidium bromide to determine the presence or absence of target bands. One or more RT-PCR products were sequenced and verified as the expected CYSDV sequence for each positive host plant species to confirm specificity of the products (TACGen, Richmond, CA).

\section{RESULTS}

CYSDV-infected melon fields were widely dispersed throughout the desert melon production region encompassing California's Imperial Valley and the Yuma, $\mathrm{AZ}$ production region during the sampling period. A small number of spring-planted fields were confirmed positive each year; however, nearly all fall-planted melon fields throughout the region became infected by October of each year, based on RT-PCR confirmation and limited sequencing. Most noncurcurbits collected from infected melon fields and nearby areas were symptomless and tested negative (68\%) for the presence of CYSDV (Table 1). However, at least one plant of the following species tested positive for the presence of CYSDV using RT-PCR with both sets of primers: alfalfa (Medicago sativa L.), snap bean (Phaseolus vulgaris L. cvs. Shade and Sahara), romaine lettuce (Lactuca sativa L., cultivar unknown), sowthistle (Sonchus sp.), Wright's groundcherry (P. wrightii Gray), silverleaf nightshade (Solanum elaeagnifolium Cav.), alkali mallow (Sida hederacea Torr.), common mallow or cheeseweed (Malva neglecta
Wallr.), lambsquarters (Chenopodium album L.), redroot pigweed (Amaranthus retroflexus L.), five hook bassia (Bassia hyssopifolia (Pall.) Kuntze), and London rocket (Sisymbrium irio L.) (Table 1, Fig. 1). In total, 12 of 21 different noncucurbit species from nine families, collected over a 2-year period, were confirmed as hosts of CYSDV. These new CYSDV hosts represent seven distinct noncucurbit families.

Of the plants collected from areas near fields in which CYSDV was detected, only groundcherry and snap bean exhibited symptoms typical of crinivirus infection, specifically interveinal yellowing and leaf brittleness. Alkali mallow ( $S$. hederacea) was often observed in the field with a generalized interveinal yellowing; however, the symptom was not consistently associated with CYSDV infection. Similarly, alfalfa (M. sativa) sometimes exhibited leaf yellowing, but not all CYSDV-infected alfalfa plants exhibited the yellowing symptom, and alfalfa plants were not tested for the presence of other viruses that could have caused the yellowing symptoms. Romaine lettuce, although infected with CYSDV, did not exhibit any visible foliar symptoms or obvious yield effects due to CYSDV infection. Redroot pigweed (A. retroflexus) and London rocket (S. irio) were observed with some interveinal yellowing, but it was unclear whether the symptoms were the result of CYSDV infection or the result of other factors. Infected silverleaf nightshade ( $S$. elaeagnifolium), five hook bassia (B. hyssopifolia),

and lambsquarters (C. album) plants were symptomless.

Identification of potential crop and weed reservoir hosts. Laboratory transmissions were conducted from CYSDVinfected melon and cucumber maintained in growth chambers at the USDA-ARS in Salinas, to a wide range of plant species that either grow as weeds or are grown commercially or privately in the American Desert Southwest, including summer and winter crop plants, weed species common to the region, and available relatives when seed of local weeds were not available. Additional laboratory test plants were also evaluated. Transmission results (Table 2) confirmed both romaine and bibb lettuce as hosts of CYSDV, as expected based on a previous report (21). Transmission tests also resulted in infection of two cultivars of snap bean, with $3 / 4$ plants of the cultivar Shade and $3 / 5$ plants of the cultivar Top Crop becoming infected with CYSDV following transmission experiments involving 75 viruliferous whiteflies (Table 2). Although a third snap bean cultivar, Sahara, was not infected during transmission tests, plants of this cultivar collected from a field in the fall of 2008 were confirmed infected with CYSDV. Transmission results also confirmed highly efficient infection of buffalo gourd ( $C$. foetidissima), a wild cucurbit common in the Sonoran Desert production region, and moderately efficient infection of $P$. wrightii, a weed prevalent in desert melon fields (Table 2). Transmission from melon to alkali

\section{A Selected Weed Hosts}

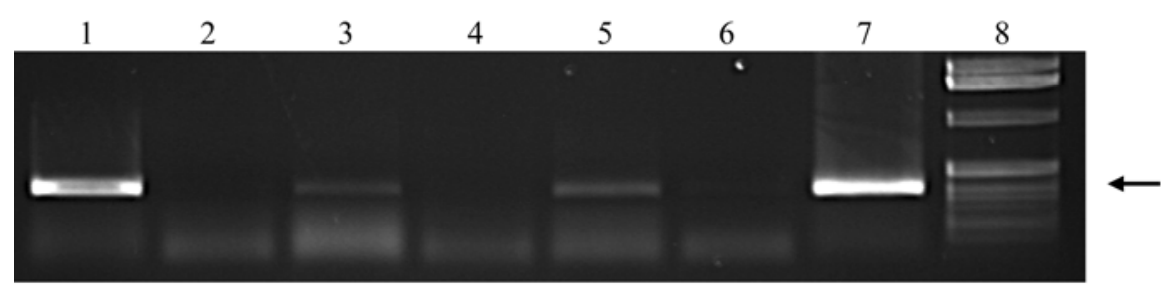

\section{B Selected Crop Hosts}

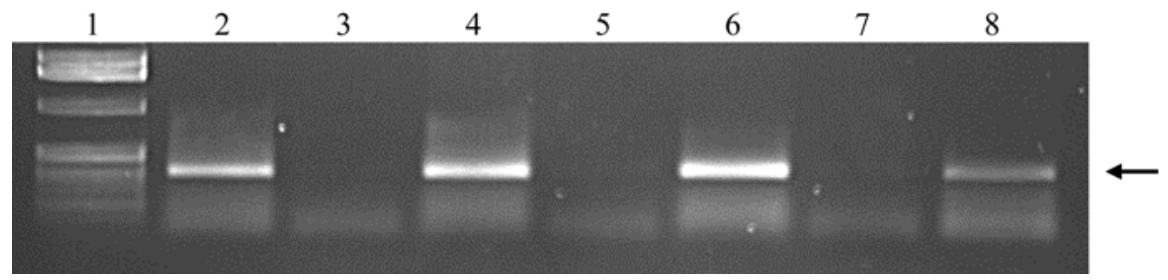

Fig. 1. Reverse transcription-polymerase chain reaction (RT-PCR) amplification of Cucurbit yellow stunting disorder virus (CYSDV) from weed and crop samples collected near melon fields in Imperial County, CA. Primers amplify a 394-bp band (location indicated by arrows) from the CYSDV coat protein gene. A, Selected weed hosts: lane 1, CYSDV-infected alkali mallow (Sida hederacea); lane 2, virus-free $S$. hederacea; lane 3, CYSDV-infected groundcherry (Physalis wrightii); lane 4, virus-free $P$. wrightii; lane 5, CYSDV-infected Chenopodium album; lane 6, virus-free Chenopodium quinoa (virusfree $C$. album was not available); lane 7, CYSDV-infected melon (Cucumis melo); lane 8, DNA size marker. B, Selected crop hosts: lane 1, DNA size marker; lane 2, CYSDV-infected melon $(C$. melo); lane 3, virus-free snap bean (Phaseolus vulgaris); lane 4, CYSDV-infected $P$. vulgaris; lane 5, virusfree alfalfa (Medicago sativa); lane 6, CYSDV-infected M. sativa; lane 7, virus-free lettuce (Lactuca sativa); lane 8, CYSDV-infected L. sativa. 
mallow ( $S$. hederacea), another common weed, resulted in very dramatic interveinal chlorosis (Fig. 2) much more distinctive than the standard yellowing that was observed in many noninfected field samples.

To determine the ability of some of the newly identified hosts to serve as virus reservoirs, additional transmission tests were conducted using sources of each host plant generated through laboratory transmission studies. Infected leaves from five of the newly identified hosts-romaine lettuce ( $L$. sativa cv. Valmaine), alkali mallow ( $S$. hederacea), snap bean ( $P$. vulgaris cv. Shade), Wright's groundcherry (P. wrightii), and buffalo gourd (C. foetidissima)—were used as CYSDV source plants for whitefly transmissions to melon, using 75 whiteflies per plant for each transmission. Experimental transmission from romaine lettuce resulted in CYSDV infection in 8/9 melon plants. Transmission of CYSDV from infected alkali mallow resulted in $6 / 17$ infected melon plants. Transmission from snap bean (P. vulgaris) resulted in 2/13 infected melons, transmission from $P$. wrightii resulted in $2 / 6$ infected melons, and all (6/6) melons became infected with CYSDV following transmission from buffalo gourd (C. foetidissima).

Transmission from field source plants confirmed to be infected with CYSDV was attempted with alfalfa (M. sativa), lettuce (L. sativa), and Wright's groundcherry ( $P$. wrightii). These tests involved using plant tissue obtained from the field and confirmed by RT-PCR to contain CYSDV. None of the transmissions were successful in individual tests using lettuce and Wright's groundcherry, or duplicated tests using alfalfa. In all cases, infected source plants had experienced significant desiccation between the time of collection in the field and arrival in the lab. Whiteflies were placed on the plant material quickly after arrival in the lab, while extraction and RTPCR were being performed to determine infection status. In all cases, however, poor whitefly feeding was observed based on the large number of dead whiteflies in the cages and limited numbers feeding on leaves at the end of virus acquisition. In contrast, field samples of CYSDV-infected melon leaves were effectively used for transmission. Transmission from fieldinfected noncucurbit host plants was discontinued due to the lack of effectiveness of this approach.

Table 2. Experimental host range ${ }^{\mathrm{a}}$ of Cucurbit yellow stunting disorder virus (CYSDV) based on transmission from cucurbit to test hosts by Bemisia tabaci biotype $\mathrm{B}^{\mathrm{b}}$

\begin{tabular}{|c|c|c|}
\hline Plant species (common name) & No. positive/no. tested & Symptoms (+/-) \\
\hline \multicolumn{3}{|l|}{ Amaranthaceae } \\
\hline Spinacia oleracea (spinach) & $0 / 10$ & - \\
\hline \multicolumn{3}{|l|}{ Brassicaceae } \\
\hline Brassica juncea (Indian mustard) & $0 / 19$ & - \\
\hline Brassica oleracea (cauliflower) & $0 / 10$ & - \\
\hline Brassica rapa (turnip) & $0 / 10$ & - \\
\hline Capsella bursa-pastoris (shepherd's purse) & $0 / 10$ & - \\
\hline \multicolumn{3}{|l|}{ Chenopodiaceae } \\
\hline Beta macrocarpa (wild beet) & $0 / 10$ & - \\
\hline Beta vulgaris (sugar beet) & $0 / 10$ & - \\
\hline Chenopodium capitatum (blite goosefoot) & $0 / 10$ & - \\
\hline \multicolumn{3}{|l|}{ Compositae } \\
\hline Lactuca sativa (bibb lettuce) & $6 / 8$ & - \\
\hline (romaine lettuce) & $5 / 10$ & _- \\
\hline \multicolumn{3}{|l|}{ Cucurbitaceae } \\
\hline Cucumis melo (melon) & $12 / 12$ & + \\
\hline Cucumis sativus (cucumber) & $35 / 36$ & + \\
\hline Cucurbita foetidissima (buffalo gourd) & $6 / 8$ & + \\
\hline \multicolumn{3}{|l|}{ Fabaceae } \\
\hline Medicago sativa (alfalfa) & $0 / 10$ & - \\
\hline Phaseolus vulgaris (snap bean) & $6 / 14$ & + \\
\hline Pisum sativum (pea) & $0 / 4$ & - \\
\hline Vicia faba (bell bean) & $0 / 8$ & - \\
\hline \multicolumn{3}{|l|}{ Malvaceae } \\
\hline Anoda abutiloides (false Indian mallow) & $0 / 9$ & - \\
\hline Gossypium hirsutum (cotton) & $0 / 10$ & - \\
\hline Sida hederacea (alkali mallow) & $6 / 7$ & + \\
\hline \multicolumn{3}{|l|}{ Solanaceae } \\
\hline Capsicum аппиит (jalapeno pepper) & $0 / 10$ & - \\
\hline Datura stramonium (jimsonweed) & $0 / 9$ & - \\
\hline Physalis wrightii (Wright's groundcherry) & $2 / 6$ & + \\
\hline Physalis floridana (downy groundcherry) & $0 / 8$ & - \\
\hline Solanum lycopersicum (tomato) & $0 / 10$ & - \\
\hline
\end{tabular}

${ }^{a}$ Infections were confirmed by reverse transcription-polymerase chain reaction using primer sets to the CYSDV coat protein and HSP70h genes as described in Materials and Methods.

${ }^{\mathrm{b}}$ Whiteflies were allowed 48-h acquisition access periods on CYSDV-infected Cucumis melo or $C$. sativus plants, followed by 48 -h transmission access to test plants. Numbers of whiteflies per inoculated plant ranged from 40 to 100 depending on availability of whiteflies for transmission at the time of experimentation.

\section{DISCUSSION}

Although the most efficient hosts of CYSDV are predominantly members of the Cucurbitaceae, noncucurbit hosts are also likely to be important for survival and maintenance of CYSDV in the environment of the American Desert Southwest, as well as in other parts of the world where these hosts or their relatives occur near cucurbit production. The studies described herein identified several cultivated and weedy plant species common to the southwestern desert melon production region that not only can be infected by CYSDV, but also can serve as reservoirs for transmission of the virus to cucurbit crops by Bemisia tabaci. This new knowledge broadens previous information on the host range of CYSDV and emphasizes the importance of additional studies on the epidemiology of this emergent virus affecting yield and quality of melons at the center of American summer melon production.

Prior to these studies, it was well known that most cucurbit crop species were highly susceptible to CYSDV. The goal of this work was not to revisit infection of cucurbits, but to identify possible noncucurbit hosts. To this end, experiments examined a wide range of plant species that either grow as weeds or are grown commercially or privately in the American Desert Southwest, including summer and winter crop plants and weed species common to the region. Three crop hosts in addition to cucurbits, alfalfa, lettuce, and snap bean, as well as several weed species were confirmed as new host plants of CYSDV. In order to avoid false positives, nucleic acid extracts of plants collected from within and around melon fields were tested using two distinct sets of RT-PCR primers, followed by sequencing for confirmation of target in each RT-PCR positive host. Further confirmation, when possible, involved laboratory-based transmission of CYSDV from melon or cucumber to the same plant species identified as infected from the field sampling, followed again by RT-PCR confirmation and selective sequencing. Finally, identification of potential reservoir hosts was determined through whitefly-transmission from selected noncucurbit hosts to melon. This three-phase approach lends a level of confidence to these studies by providing multiple levels of confirmation.

Of the three noncucurbit crop hosts of CYSDV, alfalfa is grown on the largest acreage, and is arguably the most widely grown crop in the American Desert Southwest. Its ability to be infected by CYSDV is of great concern. Similarly, this region also produces the majority of American winter lettuce, resulting in a vast amount of lettuce with the potential to sustain CYSDV over the winter months. Interestingly, it was not possible to transmit CYSDV from alfalfa. It is possible that lack of transmission was due to the age or 
quality of the infected alfalfa source plants, since it is well known that virus titers in host plants often decline with plant age, and infection of alfalfa plants in the field could date back as far as fall 2006 during the initial emergence of CYSDV in the region. Furthermore, field samples of alfalfa were somewhat desiccated upon arrival, and this may have influenced vector feeding. Future studies will examine transmission from younger, lab-inoculated alfalfa plants in an effort to clarify transmission efficiency from this host. Regardless, the ability of alfalfa to harbor CYSDV provides a perennial reservoir of the virus that would survive extended freezes, making it an essentially permanent reservoir. Further studies will need to examine the concentration of CYSDV in alfalfa, lettuce, and other newly identified hosts relative to transmission efficiency as has been done for other criniviruses (20).

Another important crop reservoir host of CYSDV is lettuce, which is grown during the winter months in the Sonoran Desert, ranging from the Imperial Valley of southeastern California to adjacent areas in western Arizona and northern Mexico. This contiguous growing region produces most of the winter lettuce for the U.S. market and encompasses broad acreage, covering much of the same area where melons are grown during the spring and fall cropping seasons. The vast acreage of lettuce during the non-melon-growing season may provide an important reservoir for the survival of CYSDV during a time in the year that whitefly populations are low and cucurbits are rare. Although only a small percentage of lettuce samples collected from the field were infected with CYSDV, this crop may still be an important source of CYSDV for transmission to cucurbits. The whitefly vector of CYSDV, B. tabaci biotype $\mathrm{B}$, readily feeds on lettuce. Furthermore, transmission studies using 75 whiteflies per plant demonstrated highly efficient transmission of CYSDV from lettuce to melon. Although 75 whiteflies per leaf is probably low for whitefly populations during the summer months, lettuce is usually grown during the cooler seasons when whitefly populations are lower. This can lead to lower efficiency of transmission due to decreased whitefly populations on plants. Due to the abundance of lettuce during the predominantly melon-free winter period, however, and the desirability of lettuce as a host for $B$. tabaci, infected lettuce may be a significant overwintering reservoir for CYSDV that could lead to transmission to cucurbits or other alternate hosts. Additional studies will be necessary to fully understand the role lettuce plays in the epidemiology of CYSDV in the southwestern desert production region.

Three snap bean varieties were tested as potential reservoir hosts for CYSDV based on the identification of infected snap bean in the Imperial Valley (Table 1). Previous studies in Spain indicated that CYSDV did not infect bean (5). Transmission tests to determine the ability of CYSDV to infect bean were particularly important since leaves of snap bean plants collected from the field had a significant amount of honeydew (excreted by whiteflies during feeding). This created concern that positive identifications on bean could have resulted from CYSDV residues deposited on the surface of the leaves during vector feeding rather than from systemic infection by the virus. Obvious prevalence of honeydew on leaves was only apparent on field isolates of bean and melon.

Transmission experiments conducted under controlled growth chamber conditions followed by RT-PCR and sequencing confirmed infectivity of CYSDV on snap bean cultivars Shade and Top Crop, whereas RT-PCR and sequencing of symptomatic field plants confirmed infection of cultivars Shade and Sahara. Infected bean plants from growth chamber transmission experiments also exhibited interveinal yellowing and stunting symptoms similar to those observed on bean plants in the field. Furthermore, CYSDV was efficiently transmitted from infected snap bean cv. Shade back to melon, demonstrating the potential of snap bean to serve as a reservoir host. It is not clear why our studies differed from those conducted in Spain (5), since similar methods were used for transmission. No cultivar was named in the Spanish study, so the possibility of limited cultivar-specific infection may exist, although this is qualified by infection of all three cultivars tested in the present study. Bean is not widely planted in the desert production region, but growers in this area and others where the two crops are grown together should be aware of the potential for bean to act as a CYSDV reservoir from which whiteflies could carry the virus into nearby melons or other cucurbits.

Other potentially important CYSDV reservoir hosts in desert areas include buffalo gourd, which grows as a perennial cucurbit in cultivated rangeland and foothill areas, and the common weeds Wright's groundcherry, silverleaf nightshade, alkali mallow, London rocket, and some Chenopodium species. All of these species are common throughout fields and rangeland
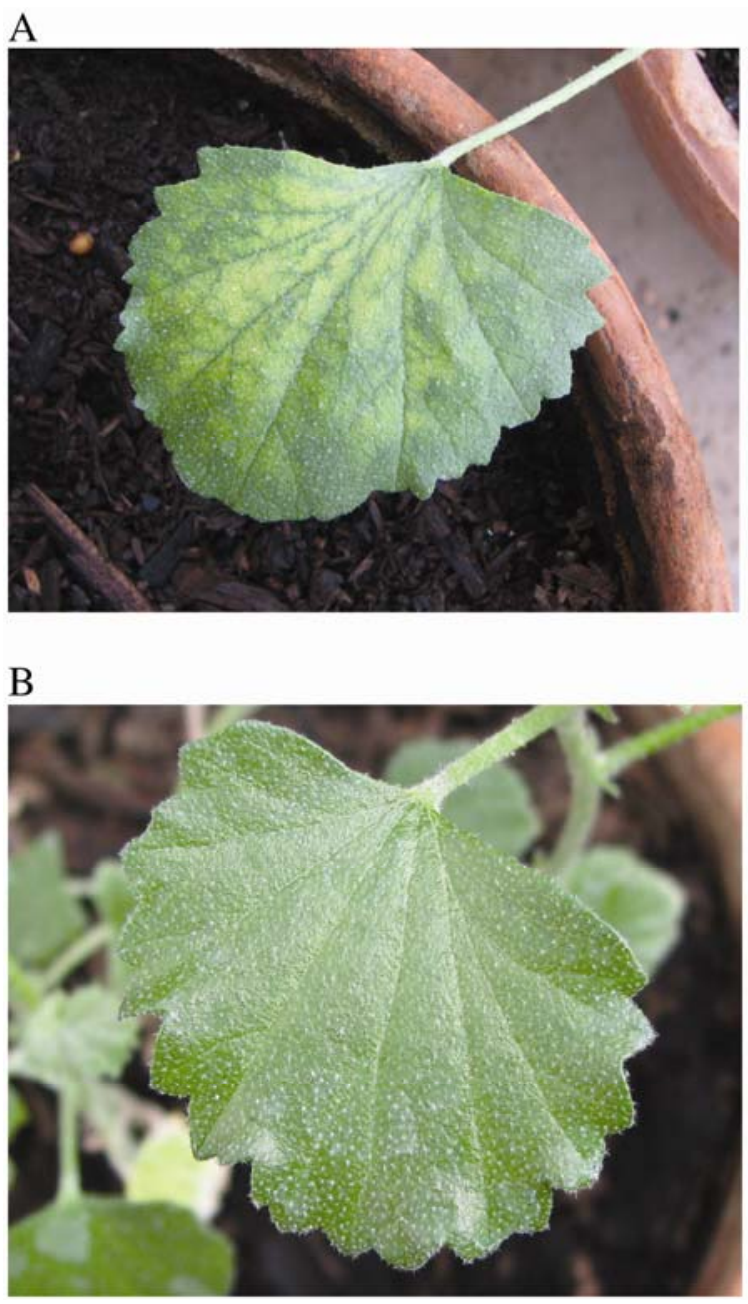

Fig. 2. Cucurbit yellow stunting disorder virus (CYSDV) symptoms of interveinal chlorosis on infected alkali mallow (Sida hederacea). A, Interveinal chlorosis on leaf of CYSDV-infected alkali mallow. B, Healthy alkali mallow leaf. 
in the Desert Southwest. Silverleaf nightshade (S. elaeagnifolium) and alkali mallow ( $S$. hederacea) are native perennials, common year-round in the desert. $P$. wrightii and Chenopodium species are annuals common throughout all but the coldest periods; however, due to low frequency of freezing temperatures (near or below $0^{\circ} \mathrm{C}$ ) in this region, both can occasionally survive through multiple seasons. Whitefly populations can be exceptionally high in the fall season throughout the desert growing regions, feeding on both preferred and nonpreferred hosts. The ability of many of the newly identified host species to persist through the winter in desert growing areas, and the abundance of these common weeds, make them potentially important reservoirs for CYSDV as well.

The roles of many of these newly identified hosts in the epidemiology of CYSDV in the Desert Southwest will require further study. $P$. wrightii is an excellent host for maintenance and transmission of a wide array of criniviruses; however, CYSDV was not transmitted to $P$. wrightii in controlled experiments as efficiently as are many other criniviruses. $P$. wrightii is widely distributed throughout the region, is a common weed in melon fields, and is a preferred feeding host for $B$. tabaci. CYSDV infection of $P$. wrightii provides an excellent reservoir from which whiteflies can acquire CYSDV, leading to transmission to cultivated cucurbits. Like P. wrightii, alkali mallow and silverleaf nightshade are widespread throughout the desert melon production area and are common in fields and along borders; and as perennials, infected plants could potentially re-emerge each year, even after a freeze. It is common to see alkali mallow with yellowing symptoms; however, these symptoms do not always correlate with infection by CYSDV. Infection of alkali mallow would provide an abundant reservoir, but only $2 / 24$ alkali mallow plants collected from fields and adjacent areas were actually confirmed to be infected with CYSDV even when cucurbits in the surrounding fields were nearly universally infected with the virus (Table 1). On the other hand, transmission from alkali mallow to melon was $35 \%$ in transmission experiments. Seed of silverleaf nightshade was not available for transmission experiments, but the high percentage of infected field plants from this species suggests it is likely significant in the overall epidemiology of CYSDV in the desert production region. Ongoing epidemiological studies should clarify the role of these and other weed hosts as potential reservoirs for transmission to cucurbits.
Buffalo gourd (C. foetidissima), a wild cucurbit species common in uncultivated areas and foothill regions of the Desert Southwest, is likely a significant reservoir host for CYSDV. Infected C. foetidissima was not found in the field during virus surveys of weed species; however, growth chamber tests demonstrated $100 \%$ infection of $C$. foetidissima test plants during transmission experiments from infected melon. Subsequent transmission back to melon from infected $C$. foetidissima also resulted in $100 \%$ infection of melons. Consequently, this perennial wild cucurbit is likely an excellent reservoir for virus survival during the winter months when crop reservoirs are not present.

There is a need for more research on factors influencing the epidemiology of CYSDV in the Desert Southwest. Information on whitefly population fluctuations, timing of initial emergence of CYSDV in spring melons and weed hosts, the impact of host plant age on virus concentration, and the role of climatic conditions in virus prevalence and vector abundance will be needed to more fully understand CYSDV epidemiology in this new environment. Information presented here, along with further analysis, will provide insight into epidemiology and lead to improved strategies to reduce impact of CYSDV in cucurbit production in the desert and in other areas. As this virus is identified in new regions throughout the world, appropriate regional host range analysis may lead to identification of further virus reservoir hosts.

\section{ACKNOWLEDGMENTS}

We thank R. L. Gilbertson for helpful discussions and assistance with field collections. We also thank Jolene Dessert and the Imperial County, CA Agricultural Commissioner's Office for assistance with field identification and plant sampling. This research was supported in part by funds provided by the California Melon Research Board, the Western IPM Center IPM Issues Grant Program (07001492-UA4), and the Western Regional IPM program (2008-03024/GRANT00383452).

\section{LITERATURE CITED}

1. Abou-Jawdah, Y., Sobh, H., Fayad, A., Lecoq, H., Delecolle, B., and Trad-Ferre, J. 2000. Cucurbit yellow stunting disorder virus-A new threat to cucurbits in Lebanon. J. Plant Pathol. 82:55-60.

2. Birdsall, S. L. 2008. Imperial County 2007 Agriculture Crop and Livestock Report. Office of the Agricultural Commissioner, Imperial County, CA.

3. Brown, J. K., Guerrero, J. C., Matheron, M., Olsen, M., and Idris, A. M. 2007. Widespread outbreak of Cucurbit yellow stunting disorder virus in melon, squash, and watermelon crops in the Sonoran Desert of Arizona and Sonora, Mexico. Plant Dis. 91:773.

4. Cantliffe, D. J., Shaw, N. L., and Stoffella, P. J. 2007. Current trends in cucurbit production in the U.S. Acta Hortic. 731:473-478.
5. Celix, A., Lopez-Sese, A., Almarza, N., Gomez-Guillamon, M. L., and Rodriguez-Cerezo, E. 1996. Characterization of Cucurbit yellow stunting disorder virus, a Bemisia tabacitransmitted closterovirus. Phytopathology 86:1370-1376.

6. Dellaporta, S., Wood, J., and Hicks, J. B. 1983. A plant DNA minipreparation: Version II. Plant Mol. Biol. Rep. 1:19-21.

7. Desbiez, C., Lecoq, H., Aboulama, S., and Peterschmitt, M. 2000. First report of Cucurbit yellow stunting disorder virus in Morocco. Plant Dis. 84:596.

8. Duffus, J. E. 1965. Beet pseudo-yellows virus, transmitted by the greenhouse whitefly (Trialeurodes vaporariorum). Phytopathology 55:450-453.

9. Frohlich, D., Torres-Jerez, I., Bedford, I. D., Markham, P. G., and Brown, J. K. 1999. A phylogeographic analysis of the Bemisia tabaci species complex based on mitochondrial DNA markers. Mol. Ecol. 8:1593-1602.

10. Hassan, A. A., and Duffus, J. E. 1991. A review of a yellowing and stunting disorder of cucurbits in the United Arab Emirates. Emir. J. Agric. Sci. 2:1-16.

11. Kao, J., Jia, L., Tian, T., Rubio, L., and Falk, B. W. 2000. First report of Cucurbit yellow stunting disorder virus (genus Crinivirus) in North America. Plant Dis. 84:101.

12. Kuo, Y.-W., Rojas, M. R., Gilbertson, R. L., and Wintermantel, W. M. 2007. First report of Cucurbit yellow stunting disorder virus in California and Arizona, in association with Cucurbit leaf crumple virus and Squash leaf curl virus. Plant Dis. 91:330.

13. Liu, H.-Y., Cohen, S., and Duffus, J. E. 1992. The use of isozyme patterns to distinguish sweetpotato whitefly (Bemisia tabaci) biotypes. Phytoparasitica 20:187-194.

14. Livieratos, I. C., and Coutts, R. H. A. 2002 Nucleotide sequence and phylogenetic analysis of Cucurbit yellow stunting disorder virus RNA2. Virus Genes 24:225-230.

15. Lopez-Sese, A. I., and Gomez-Guillamon, M. L. 2000. Resistance to Cucurbit yellow stunting disorder virus (CYSDV) in Cucumis melo L. Hortscience 35:110-113.

16. Louro, D., Vicente, M., Vaira, A. M., Accotto, G. P., and Nolasco, G. 2000. Cucurbit yellow stunting disorder virus (genus Crinivirus) associated with the yellowing disease of cucurbit crops in Portugal. Plant Dis. 84:1156.

17. Polston, J. E., Hladky, L. L., Akad, F., and Wintermantel, W. M. 2008. First report of $\mathrm{Cu}$ curbit yellow stunting disorder virus in Cucurbits in Florida. Plant Dis. 92:1251.

18. Tzanetakis, I. E., Wintermantel, W. M., and Martin, R. R. 2003. First report of Beet pseudo yellows virus in strawberry in the United States: A second crinivirus able to cause pallidosis disease. Plant Dis. 87:1398.

19. Wintermantel, W. M. 2004. Pumpkin (Cucurbita maxima and $C$. pepo), a new host of Beet pseudo yellows virus in California. Plant Dis. 88:82.

20. Wintermantel, W. M., Cortez, A. A., Anchieta, A. G., Gulati-Sakhuja, A., and Hladky, L. L. 2008. Co-infection by two criniviruses alters accumulation of each virus in a host-specific manner and influences efficiency of virus transmission. Phytopathology 98:1340-1345.

21. Wisler, G. C., Duffus, J. E., Liu, H.-Y., and Li, R. H. 1998. Ecology and epidemiology of whitefly-transmitted Closteroviruses. Plant Dis. $82: 270-280$. 